\title{
PENGEMBANGAN PROGRAM LAYANAN BEBAS PUSTAKA ONLINE UNTUK MENINGKATKAN EFEKTIFITAS DAN EFISIENSILAYANAN PERPUSTAKAAN (STUDI KASUS: UNIVERSITAS PENDIDIKAN GANESHA)
}

\author{
I Made Pendra Mahardika ${ }^{1}$, Made Darmawan ${ }^{2}$, Ni Kadek Etik Suparmini ${ }^{3}$ \\ Unit Perpustakaan UNDIKSHA \\ Singaraja, Indonesia
}
e-mail: pendramahardika77@gmail.com, dekwan869@gmail.com, etikmini@yahoo.com

\begin{abstract}
Abstrak
Tujuan dari penelitian ini adalah untuk merancang bangun program layanan bebas pustaka online dan mengetahui implementasi program layanan bebas pustaka online dalam rangka meningkatkan efektifitas dan efisiensi layanan perpustakaan. Metode penelitian yang digunakan adalah metode penelitian dan pengembangan (research and development) yang menghasilkan produk berupa software berikut pengujian terhadap keefektifan produk tersebut. Objek penelitian ini adalah mahasiswa yang mencari bebas pustaka. Data dikumpulkan menggunakan metode angket/kuisioner, observasi dan wawancara tidak terstruktur. Hasil pengumpulan data kemudian dianalisis secara deskriptif dengan memaknai hasil hitungan data kuantitatif maupun hasil data kualitatif. Hasil penelitian yang telah dicapai adalah (1) programlayanan bebas pustaka online ini sudah sesuai dengan standar mutu suatu program karena telah memenuhi kreteria seperti reliability, correctness, useability, maintainability, testability, interoperationability, flexibility dan overall satisfaction. (2) Program ini memperoleh tanggapan positif dari pustakawan (ahli perpustakaan) yang menyatakan bahwa program layanan bebas pustaka online sangat urgent untuk diterapkan pada perpustakaan UNDIKSHA, hal ini merujuk pada paradigma teknologi informasi online yang mampu memberikan layanan secara efektif, efesien dan akurat tanpa batasan ruang maupun waktu. (3) implementasi program ini mendapatkan respon sangat positif dari pengguna berdasarkan hasil ujicoba program dan respon pengguna. Hal ini ditunjukkan dari $98 \%$ pengguna setuju penerapan program ini dengan indikator relevansi (100\%), efesiensi (99,33\%), keakuratan (97\%), Kepuasan(99\%).Program layanan bebas pustaka online sudah sesuai dengan harapan dan kebutuhan pengguna.
\end{abstract}

Kata kunci :software, online, bebas Pustaka, efektifitas, efesiensi

\begin{abstract}
The purpose of this study is to design the program of online free membership services and its implementation to improve the effectiveness and defficiency of library services. The research method used research and development method. The result of this research is a software products include testing the effectiveness of these products. Objects of this study are the students of UNDIKSHA who are
\end{abstract}


looking for free membership service. Data are collected using questionnaires, observations and unstructured interviews. Results of data collection is analyzed descriptively using quantitative and qualitative data. The results of this research are: (1) this onlinefree membership program is already fulfill the program quality standards becauseit already meets the criteria such reliability, correctness, useability, maintainability, testability, interoperationability, flexibility and over all satisfaction. (2) The program received positive reviews from librarians whostatedthat online freemembership program in UNDIKSHA libraryis very urgent refers to the paradigm of online information technology in order to deliver services effectively, efficiently and accurately without limitation of space and time. (3) implementation of this program gets a very positive response from users based on program and user test results.It can be seen from the $98 \%$ of users who agreed with the implementation of this program which the relevancy indicator of $(100 \%)$, efficiency $(99.33 \%)$, accuracy (97\%), satisfaction (99\%). This program is already met the user's hope and demand.

Keywords : software, online, free membership, effectiveness, efficiency

\section{PENDAHULUAN}

Salah satu layanan pada perpustakaan Undiksha adalah layanan bebas pustaka. Menurut buku panduan penggunaan perpustakaan Undiksha 2012 bahwa layanan bebas pustaka adalah suatu layanan yang diberikan kepada anggota perpustakaan untuk mengurus surat keterangan bebas pinjam buku atau bersih pinjaman bahwa yang bersangkutan tidak memiliki pinjaman dankewajiban mahasiswa mengumpulkan hasil karya ilmiah berupa tugas akhir atau skripsi yang sudah dijilid dan softcopy atau $C D$ (compact disc). Pemberian surat ini untuk keperluan: yudisium/wisuda, pindah studi keperguruan tinggi lain dan cuti kuliah.

Berdasarkan observasi dilapangan, peneliti menemukan pelayanan yang kurang prima pada layanan bebas pustaka, ditemukan empat pokok permasalahan yang terjadi pada layanan tersebut yaitu (1) jumlah mahasiswa yang mengurus bebas pustaka terlalu banyak, (2) prasarana yang kurang optimal, (3) biaya yang tinggi dan (4) prosedur layanan yang panjang.

Jumlah mahasiswa yang mencari bebas pustaka yang terlalu banyak pada saat menjelang penutupan pendaftaran wisuda mengakibatkan antrean yang panjang. Prasarana utama yang diperlukan untuk pengecekan data tugas akhir atau skripsi dan tesis dalam bentuk softcopy $C D$ (compact disc) adalah pembaca $C D / C D$ ROM. Alat ini sering terjadi kerusakan karena intensitas penggunaan yang tinggi, tercatat kurun waktu 1 tahun sudah 4 pembaca CD/CD ROM yang optiknya sudah rusak.Biaya yang dibutuhkan sama dengan pembelian komputer empat buah, bisa dibayangkan biaya operasional yang tinggi pada pelayanan bebas pustaka. Selain itu bagi mahasiswa yang mengurus bebas pustaka wajib mengumpulkan data hasil 
karya ilmiahnya dalam bentuk softcopy berupa CD berarti diperlukan biaya tambahan untuk membeli CD dan memasukan data dengan aplikasi burn. Prosedur layanan bebas pustaka memiliki beberapa tahapan proses layanan kepada mahasiswa yang mencari surat bebas pustaka yang berlaku di perpustakaan Undiksha sebagai berikut: (1). Mahasiswa yang mencari bebas pustaka harus datang langsung ke perpustakaan. (2) Mahasiswa menyerahkan hardcopy dan softcopy karya ilmiah ke bagian pelayanan karya ilmiah di lantai 3 perpustakaan Undiksha.(3)Mahasiswa mengecek pinjaman pada bagian tata usaha perpustakaan Undiksha di bagian pembuatan kartu anggota dan (4) Pengisian kartu bebas pustaka dan blangko simpanan wajib karya ilmiah.Dengan tahapan atau prosedur yang panjang pada pelayanan bebas pustaka dapat berimplikasi pelayanan yang kurang efektif dan efesien. Menurut Baris (1980:4) sistem kerja atau layanan yang baik diperlukan efesiensi kerja atau layanan, cara pendekatan terhadap masalah peningkatan efesiensi kerja atau layanan yaitu menyerderhanakan (menyempurnakan) prosedur-prosedur pelaksanaan kerja sedemikian rupa sehingga usaha yang sama dapat diselesaikan pekerjaaan yang lebih banyak. Menurut Gibson (1996:30) mengatakan bahwa teknologi yang digunakan untuk melaksanakan pekerjaan dapat mempengaruhi efektivitas kerja/layanan, semakin tinggi teknologi yang digunakan semakin meningkat efektivitas kerja/layanannya.

Melihat fenomena tersebut tim peneliti menerapkan teknologi informasi online untuk mengatasi permasalahan yang terjadi seperti yang sudah dipaparkan di atas dengan layanan bebas pustaka online yangdapat diakses dimana dan kapan saja tanpa terbatas ruang dan waktu selama terhubung internet sehingga efesiensi biaya, waktu dan tenaga dapat terwujud.

Beberapa penelitian sebelumnya tentang sistem online yang identik dengan penelitian ini telah dilakukan oleh beberapa peneliti dengan kasus yang berbeda-beda. Arif B. Putra, dkk. (2010), telah mengembangkan Sistem Informasi Jurnal IImiah Online. Sistem yang dikembangkan merupakan sistem yang berisi tentang jurnal-jurnal ilmiah yang bisa dimanfaatkan oleh pihak luar melalui website. Tri Susilawati (2010) telah mengembangkan E-Library ini menggunakan rantai nilai yang ada di Customer Relationship Management (CRM) yaitu acquire, enhance, dan retains dalam merancang fitur-fitur yang ada seperti pustaka digital yang dapat diunduh oleh semua anggota, pendaftaran anggota secara online, catalog digital online, dan lain-lain. Fathoni Aji, (2010), mengembangkan garuda rujukan digital, yang merupakan sistem menyediakan daftar rujukan digital untuk karya ilmiah. Model arsitektur yang dibuat digunakan untuk mengabungkan data-data perpustakaan dari jenis sumber informasi. Retno Wulan dkk, (2011), telah mengembangkan layanan penelusuran koleksi skripsi dan tugas akhir dengan e-book berbasis sistem elektronic resources. Sistem yang dikembangkan merupakan layanan akses koleksi skripsi dan tugas akhir via internet.

Dari hasil kajian peneliti di atas peneliti mempertimbangkan untuk 
mengembangkan program bebas pustaka yang berbasis online untuk meningkatkan efektifitas dan efisiensi layanan bebas pustaka di perpustakaaan undiksha. Berdasarkan paparan di atas maka permasalahan dapat dirumuskan sebagai berikut :(1) Bagaimanarancang bangun program layanan bebas pustaka online dalam rangka meningkatkan efektifitas dan efisiensi layanan perpustakaan?(2) Bagaimana implementasi program layanan bebas pustaka online dalam rangka meningkatkan efektifitas dan efisiensi layanan perpustakaan?

\section{METODE PENELITIAN Desain Penelitian}

Penelitian ini bertujuan untuk mengembangkan dan mengujicoba keefektifan program layanan bebas pustaka online dalam meningkatkan efektifitas dan efisiensi layanan bebas pustaka di perpustakaan universitas pendidikan Ganesha, sehingga dalam menyusun kajian ini penulis menggunakan desain penelitian pengembangan (research and development). Objek penelitian adalah mahasiswa dan pustakawan yang terlibat langsung dalam layanan bebas pustaka, sedangkan subjek penelitian adalah programmer sebagai pembuat software dan pustakawan sebagai ahli dalam bidang kepustakawan.

\section{Populasi dan Sampel Penelitian}

Populasi penelitian ini adalah seluruh mahasiswa universitas pendidikan ganesha, sedangkan sampelnya adalah mahasiswa yang mendaftar wisuda periode oktober 2013. Penentuan sampel ini karena mahasiswa yang mendaftar periode oktober 2013 akan mencari bebas pustaka mulai april-september 2013.

\section{Prosedur Penelitian}

Prosedur yang ditempuh oleh peneliti dalam mengembangkan program, menyangkut 9 langkah menurut sugiyono (2009) seperti tergambar dalam diagram alur berikut:

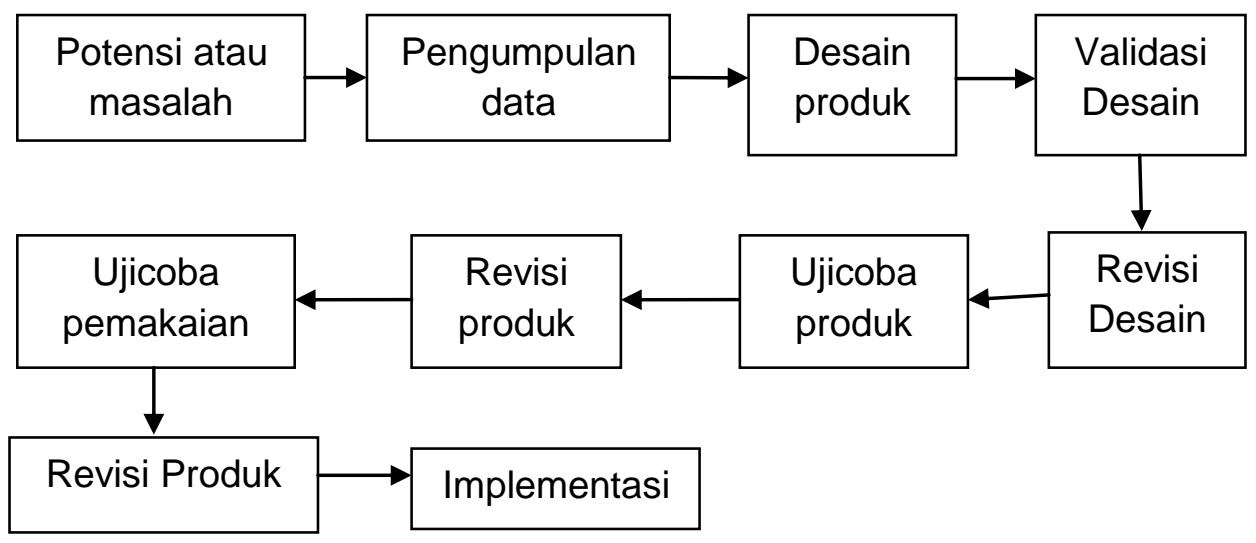




\section{Instrumen Penelitian}

Peneliti menggunakan tiga buah instrumen dalam pengumpulan data yaitu dengan kuisioner, observasi/pengamatan dan wawancara.Instrumen yang digunakan dalam memperoleh data kuantitatif adalah dengan kuesioner untuk mahasiswa yang mencari bebas pustaka, sedangkan wawancara diberikan kepada ahli teknologi informasi dan pustakawan ahli.kuisionermemuat empat indikator relevansi, efisiensi, keakuratan dan kepuasan.

\section{Analisis Data}

Data yang sudah terkumpul melalui instrumen yang terdiri dari data kuantitatif dan kualitatif, kemudian dianalisis dengan menggunakan dua teknik analisis data. Analisis data kuantitatif dilakukan dengan pentabulasian datahasil kuisioner dan catatan observasi . Selanjutnya diterapkan teknik analisis deskriptif dari hitungan data kuantitatif. Tahapan dalam analisis data kualitatif yaitu melalui (1) mentranskrip data, (2)pengelompokan data dan (3) pinjaman) maka bisa dilanjutkan ke upload file skripsi atau tugas akhir atau tesis rmahasiswa. Data yang telah masuk ke program bebas pustaka akan divalidasi oleh petugas perpustakaan secara online.Apabila data belum valid maka akan diberitahu untuk diperbaiki dan diupload lagi hingga data menjadi valid.Berikut ini flowcart program layanan bebas pustaka online: menginterpretasikan data menggunakan teknik deskriptif.

\section{HASIL DAN PEMBAHASAN Hasil Rancang Bangun Program}

Program bebas pustaka online adalah program pendaftaran dalam mengurus bebas pustaka. Dalam pengurusan bebas pustaka dibagi menjadi 3 prosedur, yang pertama pengecekan bebas pinjaman, yang kedua upload softcopy/file skripsi atau tugas akhir, yang ketiga validasi data oleh petugas perpustakaan. Aspek yang tercantum dalam pengecekan bebas pinjaman yaitu no induk mahasiswa(NIM). Aspek yang tercantum dalam upload softcopy/file skripsi atau tugas akhir yaitu judul skripsi/tugas akhir, nama, NIM, jurusan, upload file skripsi/tugas akhir. Aspek yang tercantum dalam validasi data skripsi atau tugas akhir yaitu nama,judul skripsi/tugas akhir/tesis,jurusan, file, status. Data dari pinjaman pada database sirkulasi diteruskan ke web undiksha pada program pebas pustaka online untuk pengecekan bebas pinjaman buku dan apabila tidak ada pinjaman (bebas 


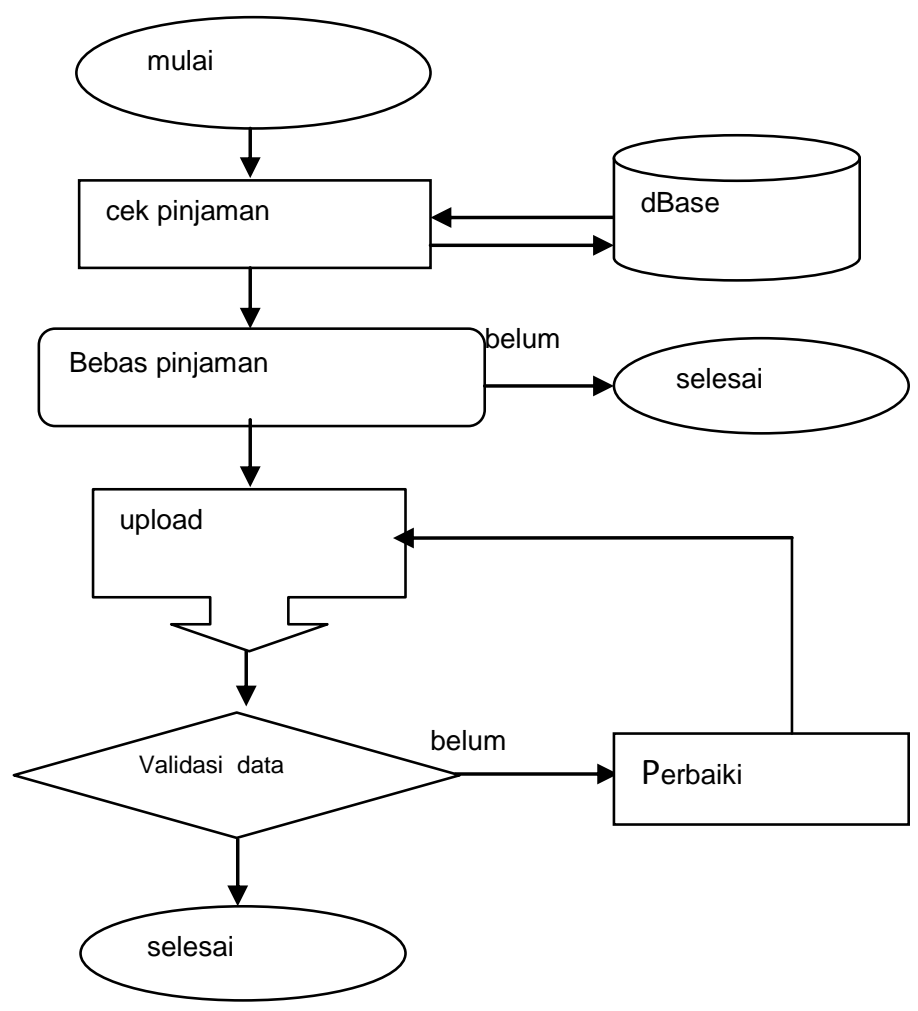

Bagan 1. Flowchart rancangan program bebas pustaka online

Berikut ini ditampilkan program bebas pustaka online:

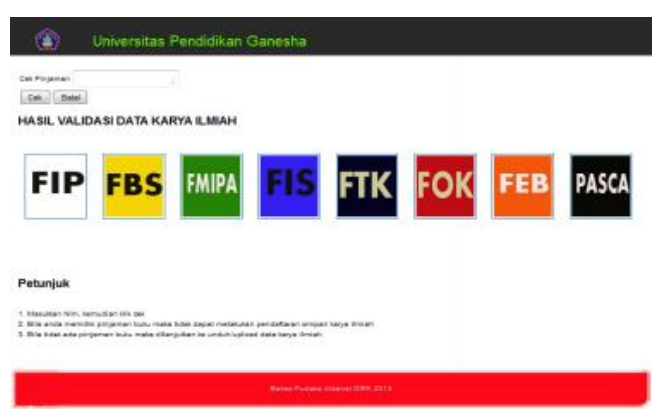

Gambar 1 Tampilan depan program

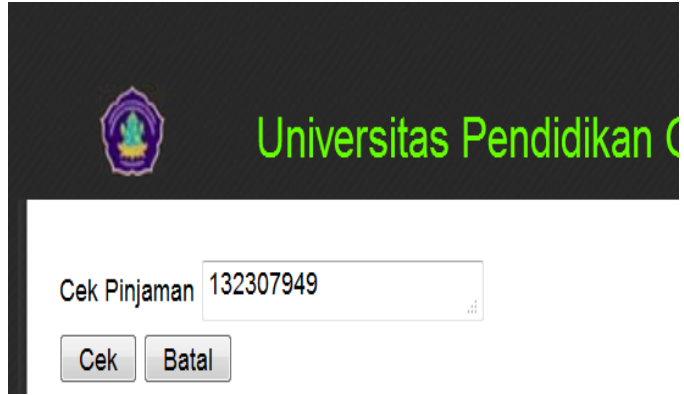

Gambar 2 Tampilan input nim untuk mengecek pinjaman 


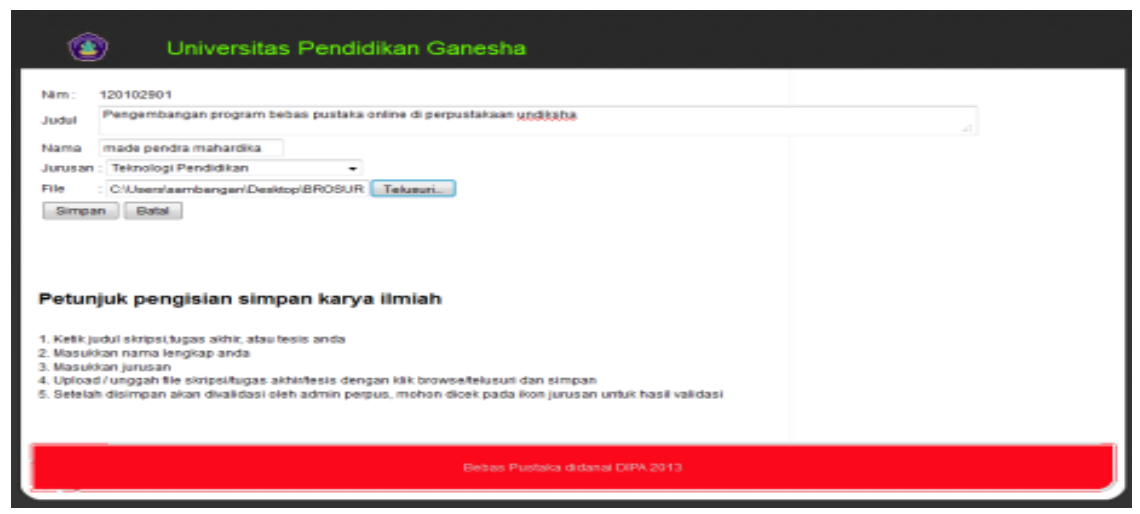

Gambar 3 Pengisian Data Wisudawan serta unduh karya ilmiah mahasiswa

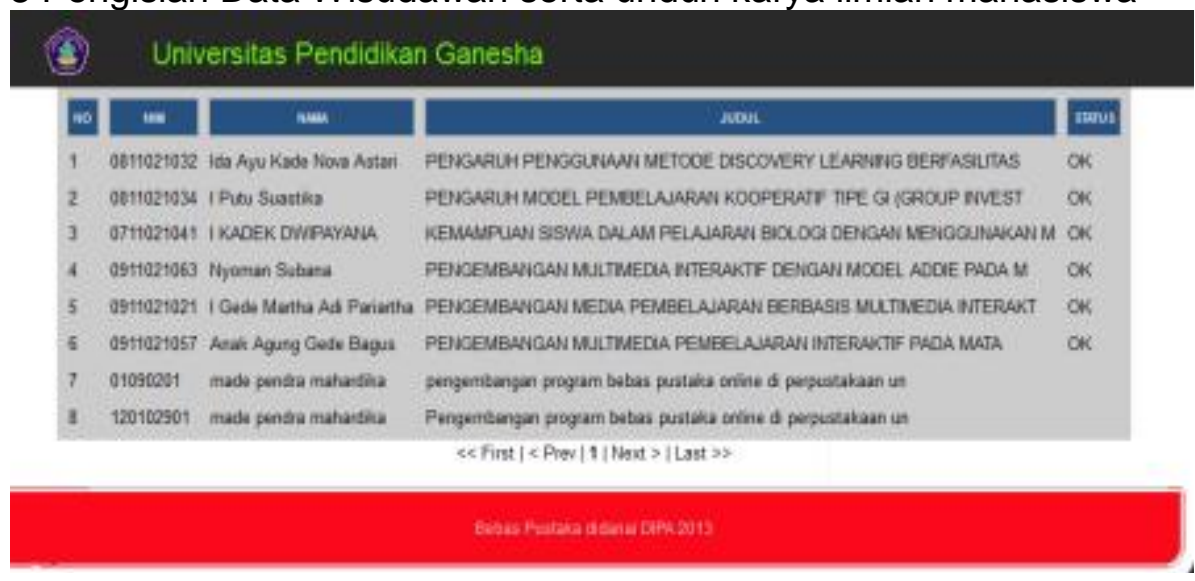

Gambar 4 Tampilan Karya IImiah yang telah diunduh mahasiswa

Untuk lebih jelas dan lengkap tentang program layanan bebas pustaka online bias diakses pada web Perpustakaan Undiksha

(http://perpustakaan.undiksha.ac.id/beb as)

\section{Hasil Implementasi Program}

Untuk mendapatkan program yang sesuai dengan standar mutu dan dapat di implementasikan dengan baik sesuai dengan harapan dan tujuan program maka peneliti melakukan validasi ahli dan ujicoba ke pengguna. Validasi ahli dilakukan oleh ahli program (programmer) dan ahli perpustakaan (pustakawan).Validasi ini merupakan validasi kualitatif yang didapatkan melalui wawancara terhadap programmer dan pustakawan.

\section{Validasi Ahli}

Hasil Validasi Dari Programmer

Validasi ahli dilakukan dengan wawancara kepada programmer. Hal ini dilakukan untuk memperoleh informasi mengenai standar mutu sebuah program berbasis komputer yang telah dirancang, dalam hal ini program bebas pustaka online. Suatu program 
dikatakan sudah sesuai dengan standar mutu jika telah memenuhi kreteria seperti: keandalan, kebenaran, kemampuan menggunakan, kemampuan memelihara, kemampuan uji, kemampuan interoperasi, keluesan, dan kepuasan menyeluruh. Berikut adalah hasil wawancara dengan programmer.

1. Keandalan/reliability, program bebas pustaka online sudah mampu menyelesaikan tugasnya dengan akurat sesuai tujuan pembuatan program. Hal ini berdasarkan ujicoba program pada pengecekan pinjaman buku yang sudah benar sesuai dengan data sirkulasi. Data pada upload karya ilmiah secara online sudah akurat dan dapat dikirim dengan cepat ke bagian admin perpus.

2. Kebenaran/corectness, Program ini sudah memenuhi spesifikasi dari tujuan pembuatan program yaitu meningkatkan efektifitas dan efesiensi layanan perpustakaan khususnya layanan bebas pustaka. Bagi mahasiswa yang mengurus bebas pustaka dapat melakukannya dengan mudah dan efesien waktu dan biaya karena tidak perlu mengumpulkan softcopy hasil karya ilmiahnya dan yang lebih menguntungkan lagi, dapat dilakukan dimana dan kapan saja. Dengan program ini sangat mampu menyelesaikan pekerjaan dengan cepat, tepat dan benar.

3.Kemampuan menggunakan/ useability, Output mudah dipelajari hanya saja program ini memiliki banyak kemungkinan dari alur prosesnya sehingga pengguna wajib membaca dan mengerti petunjuk pengisian yang ditampilkan di program.
1. Kemampuan

memelihara/maintainability

Melihat sintak yang ditampilkan terstruktur serta modul dipisah sesuai dengan kegunaan maka untuk pemeliharaan atau perbaikan dari program ini mudah dengan catatan yang memperbaiki menguasai bahasa pemrograman PHP.

2. Kemampuan uji/testability, Program dapat diuji dalam waktu singkat jika diuji dalam kalangan terbatas, artinya pengguna hanya satu dua orang tetapi jika ratusan atau ribuan itu belum bisa saya jawab karena sangat tergantung dari bandwith yang dialokasikan untuk web server dan bandwith dari pengguna atau mahasiswaPengelolaan program sudah tepat sesuai dengan mekanisme program berbasis web.

3. Kemampuan untuk interoperasi/ interoperation ability, Sistem ini sudah menggunakan standar dari pemrograman PHP sehingga jika dikaitkan dengan sesama program yang bersifat web sangat mudah dan ini sudah dilakukan dimana program ini berada di bawah dari undiksha.ac.id dan sub dari website perpustakaan.undiksha.ac.id.

4. Keluwesan/flexibility, Perubahan dari program ini tidaklah mudah karena terdiri dari beberapa modul yang saling terkait dan sub demi sub, tetapi perubahan itu masih bisa dilakukan.

5. Kepuasan menyeluruh/ overall satisfaction. Program ini sudah sesuai dengan harapan dan untuk kedepannya, program ini ditingkatkan agar lebih memudahkan petugas dan pengguna tidak perlu menunggu waktu validasi dari petugas. 
Tentu saja senang karena banyak membantu pada administrasi dan layanan khususnya di perpustakaan

\section{Hasil Validasi Dari Pustakawan}

Pustakawan yang dipilih sebagai validator program bebas pustaka online adalah pustakawan yang bertugas pada pendaftaran bebas pustaka yang akan memvalidasi data mahasiswa yang mendaftar bebas pustaka. Berikut ini hasil wawancara dengan pustakawan :

Program bebas pustaka online sudah sesuai dengan kebutuhan pengguna. Hal ini dapat dilihat dari modul yang ada pada program layanan ini seperti pengecekan pinjaman, simpan karya ilmiah mahasiswa dan validasi data untuk mengecek file agar sesuai dengan prosedur yang ditetapkan. Semua hal itu dilakukan secara online sehingga layanan dapat lebih efektif dan efesien waktu karena dapat dilakukan dimana dan kapan saja tanpa batasan waktu dan ruang.

Program ini mudah dipahami dan dioperasikan, pada saaat sekarang ini teknologi informasi online sudah tidak asing lagi, sudah banyak pekerjaan atau layanan secara online diterapkan di UNDIKSHA. Apalagi pada program ini sudah ada pedoman /petunjuk pengisian data.

Program ini mudah dipahami dan dioperasikan sehingga tidak mendapatkan permasalahan yang berarti, Cuma yang sering terjadi pada teknologi online pada saat pengguna internet pada web yang bersangkutan banyak yang menggunakan sehingga program ini menjadi lambat, tapi itu bisa diantisipasi dengan menghindari penggunaan program ini pada waktu banyak menggunakannya.

Penerapan program bebas pustaka online pada perpustakaan UNDIKSHA sudah harus dilakukan karena dengan program ini mampu memberikan layanan secara efektif, efesien dan akurat tanpa batasan ruang dan waktu, sehingga permasalahan yang sudah sering terjadi pada layanan bebas pustaka manual dapat diatasi.

Backup data karya ilmiah mahasiswa yang sudah diupload oleh mahasiswa diberikan server data yang aman dan kapasitas penyimpanan yang memadai. Pustakawan juga menyarankan data dibackup ke internet. Disamping itu juga backup pimpinan perpustakaan yang mensupport dan memberikan keputusan tentang layanan perpustakaan serta kemajuan perpustakaan.

Penerapan program bebas pustaka online dapat meningkatkan efesiensi dan efektifitas layanan perpustakaan khususnya layanan bebas pustaka karena dengan menggunakan program ini efesiensi tenaga yang melayani, kecepatan akses informasi (retrival information) dan keakuratan data serta pelayanan yang tidak terbatas pada ruang dan waktu yang disebut pelayanan

online fulltime atau online 24 jam merupakan transformasi pelayanan yang lebih baik sehingga mampu meningkatkan kepuasan pengguna perpustakaan.

\section{Hasil Ujicoba Program Kepada pengguna}

Program ini diujicobakan kepada pengguna atau mahasiswa yang 
mencari bebas pustaka periode wisuda bulan Oktober 2013 sambil memberikan angket untuk mengetahui isi, keterbacaan dan efektifitas dari program layanan bebas pustaka online.Angket disebarkan kepada 100 orang pengguna. Angket mengandung empat indikator penting seperti relevansi, efesiensi, keakuratan, dan kepuasan pemakai. Pada dimensi relevansi terdapat lima butir item pernyataan, dimensi efesiensi terdapat empat butir item pernyataan, dimensi keakuratan terdapat tiga butir item pernyataan, dimensi kepuasan pemakai terdapat lima butir item pernyataan. Pilihan jawaban untuk pernyataan tersebut ada dua yaitu "ya" jika setuju dan "tidak" jika tidak setuju. Berikut adalah tabel respon pengguna terhadap program bebas pustaka.

Tabel 1. Hasil Uji Coba Validasi

\begin{tabular}{|c|c|c|c|}
\hline No & Indikator & Deskripsi Validasi & Hasil Validasi \\
\hline 1 & Relevansi & $\begin{array}{l}\text { sasaran, tujuan dan manfaat } \\
\text { program bebas pustaka online } \\
\text { dalam memudahkan untuk } \\
\text { mengurus bebas pinjaman, } \\
\text { mengunduh softcopy karya } \\
\text { ilmiah mahasiswa, mudah } \\
\text { diakses meningkatkan efisiensi } \\
\text { dan efektifitas layanan } \\
\text { perpustakaan Undiksha. }\end{array}$ & $\begin{array}{l}\text { Pada hasil validasi ini } \\
\text { menunjukkan rerata 100\% } \\
\text { responden setuju dengan } \\
\text { adanya relevansi program } \\
\text { bebas pustaka online dalam } \\
\text { meningkatkan efesiensi dan } \\
\text { efektifitas } \\
\text { perpustakaan. }\end{array}$ \\
\hline 2 & Efesiensi & $\begin{array}{l}\text { efesiensi program ini dalam } \\
\text { mengurus bebas pustaka dinilai } \\
\text { dari efesiensi waktu, biaya dan } \\
\text { kemudahan yang diperoleh oleh } \\
\text { pengguna }\end{array}$ & $\begin{array}{l}\text { rerata } 99,33 \% \text { setuju berarti } \\
\text { responden sebagian besar } \\
\text { setuju dengan program bebas } \\
\text { pustaka dapat memberikan } \\
\text { kontribusi terhadap efesiensi } \\
\text { layanan perpustakaan }\end{array}$ \\
\hline 3 & Keakuratan & $\begin{array}{l}\text { keakuratan data dan bahasa } \\
\text { yang jelas pada program ini } \\
\text { meliputi : data pada } \\
\text { pengecekan pinjaman buku dan } \\
\text { upload data karya ilmiah pada } \\
\text { program bebas pustaka online } \\
\text { sudah akurat dan bahasa yang } \\
\text { digunakan dalam program } \\
\text { bebas pustaka online dapat } \\
\text { mudah di pahami }\end{array}$ & $\begin{array}{l}\text { Rerata } 97 \% \text { setuju berarti } \\
\text { sebagian besar responden } \\
\text { setuju dengan keakuratan data } \\
\text { dan bahasa yang jelas dan } \\
\text { mudah dipahami pada program } \\
\text { ini }\end{array}$ \\
\hline
\end{tabular}




\begin{tabular}{|l|l|l|l|}
\hline 4 & Kepuasan & $\begin{array}{l}\text { kepuasan pengguna terhadap } \\
\text { implementasi program ini, } \\
\text { tampilan interfacenya, bisa } \\
\text { mudah diakses dimana dan } \\
\text { kapan saja }\end{array}$ & $\begin{array}{l}\text { pengguna puas tidasi diperoleh 99\% } \\
\text { program bebas pustaka online. }\end{array}$ \\
\hline
\end{tabular}

\section{PEMBAHASAN}

Program bebas pustaka online dirancang sesuai dengan kebutuhan pengguna dalam pelayanan bebas pustaka. Rancang bangun program bebas pustaka online dibagi menjadi 3 modul penting yaitu (1) modul cek pinjaman buku (2) modul upload data karya ilmiah mahasiswa (3) modul validasi data karya ilmiah mahasiswa (lihat sub 4.1.1). Setelah program dirancang bangun maka selanjutnya diujicobadengan melakukan validasi ahli baik dari ahli program (programmer) serta ahli perpustakaan (pustakawan) dan validasi pengguna untuk mendapatkan program yang sesuai dengan standar mutu dan dapat di implementasikan dengan baik sesuai dengan harapan dan tujuan program.

Dari hasil penelitian ini diperoleh 3 temuan penting yaitu : (1) program layanan bebas pustaka online ini sudah sesuai dengan standar mutu suatu program karena telah memenuhi kreteria seperti reliability, correctness, useability, maintainability, testability, interoperationability, flekxibility, overall satisfaction, hal ini berdasarkan hasil validasi ahli programmer. (2) Program ini memperoleh tanggapan positif dari pustakawan (ahli perpustakaan) yang menyatakan bahwa program layanan bebas pustaka online sangat urgent untuk diterapkan pada perpustakaan UNDIKSHA, hal ini merujuk pada paradigma teknologi informasi online yang mampu memberikan layanan secara efektif, efesien dan akurat tanpa batasan ruang maupun waktu. (3) implementasi program ini mendapatkan respon sangat positif dari pengguna berdasarkan hasil ujicoba program dan respon pengguna. Hal ini ditunjukkan dari $98 \%$ pengguna setuju penerapan program ini dengan indikator relevansi $(100 \%)$, efesiensi $(99,33 \%)$, keakuratan (97\%), Kepuasan (99\%). Berdasarkan hal tersebut berarti program layanan bebas pustaka online sudah sesuai dengan harapan dan kebutuhan pengguna.

Berdasarkan paradigma perkembangan teknologi informasi online dan hasil ujicoba program layanan bebas pustaka online dapat dinyatakan bahwa program ini dapat memberikan efektifitas dan efesiensi layanan bebas pustaka pada khususnya dan layanan perpustakaan UNDIKSHA pada umumnya. Layanan bebas pustaka online sudah dapat diakses di web UNDIKSHA (http://perpustakaan. undiksha .ac.id/bebas.). Hasil temuan ini apabila diimplementasikan pada perpustakaan online juga diyakini mampu meningkatkan efektifitas dan efesiensi layanan perpustakaan khususnya layanan bebas pustaka.

Beberapa penelitian sebelumnya tentang sistem online yang identik 
dengan penelitian ini telah dilakukan oleh beberapa peneliti dengan kasus yang berbeda-beda. Arif B. Putra, dkk. (2010), telah mengembangkan Sistem Informasi Jurnal IImiah Online. Sistem yang dikembangkan merupakan sistem yang berisi tentang jurnal-jurnal ilmiah yang bisa dimanfaatkan oleh pihak luar melalui website. Tri Susilawati (2010) telah mengembangkan E-Library ini menggunakan rantai nilai yang ada di Customer Relationship Management (CRM) yaitu acquire, enhance, dan retains dalam merancang fitur-fitur yang ada seperti pustaka digital yang dapat diunduh oleh semua anggota, pendaftaran anggota secara online, catalog digital online, dan lain-lain. Fathoni Aji, (2010), mengembangkan garuda rujukan digital, yang merupakan sistem menyediakan daftar rujukan digital untuk karya ilmiah. Model arsitektur yang dibuat digunakan untuk mengabungkan data perpustakaan dari jenis sumber informasi. Retno Wulan dkk, (2011), telah mengembangkan layanan penelusuran koleksi skripsi dan tugas akhir dengan e-book berbasis sistem elektronic resources. Sistem yang dikembangkan merupakan layanan akses koleksi skripsi dan tugas akhir via internet.

Dari beberapa penelitian tersebut yang semuanya mengkaji sistem online seperti jurnal ilmiah online,pustaka digital,daftar rujukan digital untuk karya ilmiah, pendaftaran anggota secara online dan layanan penelusuran koleksi skripsi dan tugas akhir dengan e-book berbasis sistem elektronic resources.

Sedangkanpada penelitian ini mengkaji tentang layanan bebas pustaka online, dimana pemustaka dapat melakukan pendaftaran bebas pustaka atau bebas pinjaman buku untuk keperluan pendaftaran wisuda melalui internet.Selain itu pada layanan ini juga dapat dilakukan simpan karya ilmiah dengan mengunduh file karya ilmiah secara online.Jadi keunggulan dari layanan bebas pustaka online ini dapat melakukan pekerjaan dua sekaligus pendaftaran bebas pinjaman dan simpan karya ilmiah secara online.

\section{SIMPULAN DAN SARAN Simpulan}

Berdasarkan hasil dan pembahasan di atas maka dapat disimpulkan sebagai berikut : (1) program layanan bebas pustaka online ini sudah sesuai dengan standar mutu suatu program karena telah memenuhi kreteria: reliability, correctness, useability, maintainability, testability, interoperation ability, flekxibility, overall satisfaction. (2) implementasi program layanan bebas pustaka online mendapatkan respon sangat positif dari pengguna berdasarkan hasil ujicoba program dan respon pengguna, hal tersebut menunjukkan bahwa program ini sudah sesuai dengan harapan dan kebutuhan pengguna. (3) program ini dapat memberikan efektifitas dan efesiensi layanan bebas pustaka pada khususnya dan layanan perpustakaan UNDIKSHA pada umumnya.

\section{SARAN}

Layanan bebas pustaka merupakan suatu sistem yang terdiri dari sub sistem yang saling terkait satu dengan yang lainnya seperti program layanan bebas pustaka online, petugas,pengguna dan hardware maka untuk kelancaran dan keberhasilan 
layanan tersebut harus adanya sinergis antara sub sistem secara holistik.

Dalam implementasi program ini yang digunakan secara luas dengan pengguna yang banyak maka perlu diperhatikan penyimpanan database yang memadai, bandwith yang sesuai dengan kapasitas file hasil karya ilmiah mahasiswa serta kelancaran akses internet.

Program layanan bebas pustaka online perlu kiranya disempurnakan untuk kemudahan akses dan kecepatan layanan yaitu pada prosedur pendaftaran bebas pustaka yang lebih pendek lagi dengan mengefesiensikan atau pengurangan modul pada validasi data.

Pada layanan perpustakaan selain layanan bebas pustaka diharapkan dapat ditingkatkan kualitas layanannya dengan penerapan teknologi informasi online kalau hal tersebut memungkinkan, tentu saja harus melalui studi pendahuluan atau analisis sistem terlebih dahulu.

\section{UCAPAN TERIMA KASIH}

Penghargaan dan terima kasih diberikan kepada Direktur Pembinaan Penelitian dan Pengabdian Kepada Masyarakat (Ditbinlitabmas) Direktorat Jenderal Pendidikan Tinggi Depdiknas yang telah memberikan bantuan dana sehingga penelitian ini dapat berjalan sesuai rencana dan keinginan peneliti. Penelitian ini dibiayai dari dana DIPA Universitas Pendidikan Ganesha dengan SPK Nomor : 88/UN48. 14/PL/2013 Tanggal 1 April 2013

\section{DAFTAR PUSTAKA}

Arif B. Putra N, dkk. (2010). Perancangan Sistem Informasi
Jurnal Ilmiah Dengan Pencarian Berbasis Bahasa

Alami. Prosiding Seminar

Nasional Aplikasi Teknologi Informasi 2010 (SNATI 2010) ISSN: 1907-5022. Yogyakarta, 19 Juni 2010

Barish, Norman N. (1980) Analisa Administrasi. Diterjemahkan oleh Pamudji. Bina Aksara, Jakarta

\begin{tabular}{|c|c|c|}
\hline \multirow[t]{3}{*}{ Buku } & $\begin{array}{l}\text { Panduan } \\
\text { Perpustakaan }\end{array}$ & $\begin{array}{l}\text { Penggunaan } \\
\text { Universitas }\end{array}$ \\
\hline & Pendidikan & esha. (2012). \\
\hline & $\begin{array}{l}\text { Singaraja: } \\
\text { Undiksha }\end{array}$ & Perpusta \\
\hline
\end{tabular}

Corbin, J.1(985) .Managing The Library Automation

Project.Canada:Oryx Press.

Hamad, I. (2010).Transformasi Kultural Menuju Masyarakat Informasi.Jurnal dialog Kebijakan Publik. 10(35)

Hidayat, Taufik Surya. (2003).Analisa dan Perancangan Sistem Pengisian Formulir Rencana Studi Secara Online di STIMIK Perbanas. Jakarta:STMIK Perbanas

Irmayati. (2011). Pengembangan Perpustakaan Digital Puslata UT dalam Mendukung Sistem Belajar Jarak Jauh.Jurnal Teknodik.Vol. XV No. 2(183)

Gibson, James. (1996). Organisasi. Diterjemahkan Nunuk Adiarni. Binarupa Aksara, Jakarta. 
Pramita Utami, Ni Putu. (2011).Pengembangan Program Notifikasi Berbasis Komputer Untuk Memperlancar Proses Pengembalian Buku Pinjaman Pada Perpustakaan Universitas Pendidikan Ganesha. Laporan Penelitian DIPA. Lembaga Penelitian Undiksha

Retno Wulan, Ni Gusti Ayu Ketut,dkk. (2011). Pengembangan Layanan Penelusuran Koleksi Skripsi dan Tugas Akhir Dengan E-Book Berbasis Sistem Electronic Resources di Perpustakaan Universitas Pendidikan Ganesha. Laporan Penelitian DIPA. Lembaga Penelitian Undiksha

Rizal Fathoni Aji, (2010). Pengembangan Garuda (Garba Rujukan Digital) Sebagai Sumber Rujukan Karya Ilmiah Di Indonesia. Prosiding Seminar Nasional Aplikasi Teknologi
Informasi 2010 (SNATI 2010) ISSN: 1907-5022 Yogyakarta, 19 Juni 2010

Sugiarti, Yuni.(2011). Peranan Teknologi Internet dalam Membangun Pendidikan Karakter Anak.Jurnal Teknodik. Vol. XXV No.2 (145)

Sugiyono. (2009). Metode Penelitian Kuantitatif, Kualitatif dan R\&D. Bandung:Alfabeta

Tri Susilowati, (2010). Rancang Bangun E-Library Berbasis Customer Relationship Management (CRM) Studi Kasus STMIK Pringsewu. Prosiding Konferensi Nasional Sistem dan Informatika 2010. ISSN: 1979-9845. Bali, 13 Nopember 2010

Welnadi. (2010).Dinamika Informasi dan Hukum di Dunia Maya.Jurnal Dialog KebijakanPublik.10 (8). 